\title{
Evaluation of oregano essential oil as a growth promoter and resistance stimulator against Ichthyophthirius multifiliis (Protozoa, Ciliophora) in silver catfish juveniles, Rhamdia sp. (Siluriformes, Heptapteridae)
}

\section{Avaliação de óleo essencial de orégano como promotor de crescimento e resistência ao ectoparasita Ichthyophthirius multifiliis (Protozoa, Ciliophora) em juvenis de jundiá, Rhamdia sp. (Siluriformes, Heptapteridae)}

\author{
Leonardo Miguel Cararo'; Ricardo Yuji $\mathrm{Sado}^{2}$; Betina Muelbert; \\ Maude Regina de Borba $^{3 *}$
}

\begin{abstract}
Agroecology-based aquaculture emerges as a particularly interesting production alternative for rural family farmers. In such systems, it is desirable to use means for enhancing the zootechnical performance and improving fish immune responses from natural products. Thus, the present study aimed to evaluate the effect of organic diet supplementation with oregano essential oil, Origanum vulgare, on zootechnical performance, hematological parameters, and resistance to the ectoparasite Ichthyophthirius multifiliis (ich) in silver catfish juveniles, Rhamdia sp. A completely randomized design with five treatments (concentrations $0,0.5,1.0,1.5$, and $2.0 \mathrm{~g}$ oregano essential oil kg${ }^{-1}$ diet) and four replicates was adopted. Groups of 20 silver catfish juveniles (initial weight $12.5 \pm 0.5 \mathrm{~g}$ ) were stocked in 20 polyethylene tanks (54 L usable volume) connected to a water recirculation system with individual aeration. The diets were prepared with certified organic ingredients and offered for 89 days in two meals a day. At the end of the experimental period, survival, zootechnical performance, hematological parameters, and fish body composition were evaluated. After the final biometry, an experimental challenge with ich infection was performed. Dietary concentrations of oregano essential oil had no effects on growth, hematology, and body composition of silver catfish juveniles $(p>0.05)$. Neither was there any influence on the level of infection and accumulated mortality of the fish under challenge with ich. Supplementation with oregano essential oil did not prove to be an effective dietary additive in improving the performance or increasing resistance against ich in silver catfish juveniles. However, in view of the importance of the topic, further studies should be carried out to increase knowledge about the effect of this and other natural additives in silver catfish, including at other stages of development.
\end{abstract}

Key words: Natural additive. Sustainable aquaculture. Experimental challenge. Zootechnical performance. Sanity.

\footnotetext{
1 Discente, Curso de Mestrado, Programa de Pós-Graduação em Agroecologia e Desenvolvimento Rural Sustentável, Universidade Federal da Fronteira Sul, UFFS, Laranjeiras do Sul, PR, Brasil. E-mail: orarac@hotmail.com

2 Prof. Dr., Departamento de Zootecnia, Programa de Pós-Graduação em Zootecnia, Universidade Tecnológica Federal do Paraná, UTFPR, Dois Vizinhos, PR, Brasil. E-mail: ricardoysado@utfpr.edu.br

3 Prof ${ }^{\text {as }}$ Dr ${ }^{\text {as }}$, Curso de Graduação em Engenharia de Aquicultura, Programa de Pós-Graduação em Agroecologia e Desenvolvimento Rural Sustentável, UFFS, Laranjeiras do Sul, PR, Brasil. E-mail: betina.muelbert@uffs.edu.br; maude.borba@uffs.edu.br Author for correspondence
} 


\section{Resumo}

A aquicultura de base agroecológica surge como alternativa de produção especialmente interessante para os agricultores familiares rurais. Em tais sistemas, é desejável a utilização de meios que possibilitem melhorar o desempenho zootécnico e fortalecimento do sistema imune dos peixes, a partir de produtos naturais. Neste sentido, objetivou-se com o presente estudo avaliar o efeito da suplementação de dieta orgânica com óleo essencial de orégano, Origanum vulgare, sobre o desempenho zootécnico, parâmetros hematológicos e resistência ao ectoparasita ictio, Ichthyophthirius multifiliis, em juvenis de jundiá, Rhamdia sp. Foi adotado um delineamento inteiramente ao acaso, com 5 tratamentos (concentrações $0 ; 0,5 ; 1,0 ; 1,5$ e $2,0 \mathrm{~g}$ de óleo essencial de orégano $\mathrm{kg}^{-1}$ de dieta) e 4 repetições. Grupos de 20 juvenis de jundiá (peso inicial 12,5 $\pm 0,5 \mathrm{~g}$ ) foram estocados em 20 tanques de polietileno ( $54 \mathrm{~L}$ volume útil) conectados a um sistema de recirculação de água, com aeração individual. As dietas foram preparadas com ingredientes orgânicos certificados e ofertadas durante 89 dias, em duas refeições diárias. Ao final do período experimental, foram avaliados a sobrevivência, desempenho zootécnico, parâmetros hematológicos e composição corporal dos peixes. Após a biometria final, realizou-se o desafio com infestação experimental por ictio. Não houve efeito $(p>0,05)$ das concentrações de óleo essencial de orégano na dieta sobre o crescimento, hematologia e composição corporal dos juvenis de jundiá. Tampouco foi verificada influência sobre o grau de infestação e mortalidade acumulada dos peixes submetidos ao desafio com ictio. O óleo essencial de orégano não se mostrou um aditivo dietético efetivo na melhora do desempenho ou aumento da resistência contra o ictio em juvenis de jundiá. Todavia, tendo em vista a importância do tema, mais estudos devem ser realizados para ampliação do conhecimento sobre o efeito deste e outros aditivos naturais em jundiás, inclusive em outras fases de desenvolvimento.

Palavras-chave: Aditivo natural. Aquicultura sustentável. Desafio. Desempenho zootécnico. Sanidade.

\section{Introduction}

Aquaculture is the fastest growing animal foodproducing sector in the world, whose potential to meet the challenges of food security, and generate jobs and economic gains have been clearly demonstrated (HLPE, 2014; FAO, 2016). Therefore, it is essential to find ways to develop the activity in a sustainable way, seeking to increase production without compromising natural resources, based on a vision of food and nutritional security (SOUZA, 2010; HLPE, 2014). In this regard, fish production in organic/agroecological systems becomes an important alternative, since it is bases in principles that minimizes the negative impacts of the activity and adds value to the final products (BOSCOLO et al., 2012; MUELBERT et al., 2016).

Organic aquaculture in Brazil is ruled by the Interministerial Normative Instruction MAPA/ MPA No. 28, of June 8, 2011, which establishes technical standards and general requirements for environmental, economic, and social issues, as well as animal welfare, use of inputs, among other criteria for organic systems of aquaculture production. The regulation recommends a production system that preferably uses native species and prohibit the use of antibiotics, as well as other synthetic feed additives (BRASIL, 2011).

Among the several native species with potential for aquaculture, silver catfish (Rhamdia sp.), also known as jundiá, stands out especially for cultivation in the southern region of Brazil, as it is a fish adapted to the cold climate of the region, showing continuous growth in the months of winter (FRACALOSSI et al., 2004). The species also presents other desirable characteristics, such as meat quality, the absence of intramuscular spines, good palatability, management resistance, and docility (BALDISSEROTTO; RADÜNZ NETO, 2005). However, despite its characteristics of interest, the obstacle to the production of silver 
catfish is the high susceptibility to the ectoparasite Ichthyophthirius multifiliis, popularly known as ich, which causes the disease known as "white spot disease" or Ichthyophthiriasis, commonly treated with toxic substances to men and the environment (BORBA et al., 2007; PÁDUA et al., 2012).

In this context, as an alternative to the use of synthetic chemotherapeutics, several natural products based on aromatic plants have drawn great attention and have been studied in different species of zootechnical interest, such as fish (ABBAS et al., 2012; CHAVES et al., 2011; GIANNENAS et al., 2003; MICHIELS et al., 2010; ZHENG et al., 2009). The search for alternative additives with the potential to enhance zootechnical performance and improve the immune system of the animal without leaving any residue in the fish meat or resulting in resistant bacteria has driven research on the inclusion of natural products in fish diets (CAMPAGNOLO et al., 2013). Among these products, the essential oil of oregano, Origanum sp., has been distinguished not only as a growth promoter (FERREIRA et al., 2014) but also as an antioxidant and antimicrobial (ZHENG et al., 2009). However, there are also reports of studies in which the use of this additive in the diet had no effect on the performance or health of some fish species (VOLPATTI et al., 2014; YILMAZ et al., 2015).

Thus, the objective of this study was to evaluate the efficacy of feed supplementation with different concentrations of oregano essential oil, Origanum vulgare, in the performance optimization of silver catfish, Rhamdia sp., and in the resistance to the ectoparasite I. multifiliis.

\section{Material e Methods}

\section{Fish and experimental conditions}

The present study was carried out in the facilities of the Aquaculture Laboratories of the Federal University of Fronteira Sul (UFFS), Campus of Laranjeiras do Sul, Paraná, Brazil, from January to April 2016. Groups of 20 juveniles of silver catfish, Rhamdia sp. (Initial weight: $12.5 \pm 0.5 \mathrm{~g}$ ), from induced reproduction carried out at the Fish Farming Laboratory of the UFFS, were stocked in 20 polyethylene tanks $(34 \times 32 \times 65.5 \mathrm{~cm}$, useful volume $54 \mathrm{~L}$ ), connected to a recirculating system with continuous flow of heated and salinized water, with individual aeration. After three days of adaptation to the experimental conditions, during which the fish were fed twice a day with the control diet (without oregano essential oil), the experiment was started. The experimental design was completely randomized and each of the five experimental diets (Table 1) was distributed to four groups of fish. Silver catfish juveniles were fed to apparent satiety twice a day (9:00 a.m. and 5:00 p.m.) for 89 days and the amount of diet provided for each experimental unit was recorded daily. 
Table 1. Ingredients and centesimal composition of experimental diets $\left(\mathrm{g} \mathrm{kg}^{-1}\right.$ dry matter) distributed to four groups of juveniles of Rhamdia sp. for 89 days.

\begin{tabular}{|c|c|c|c|c|c|}
\hline \multirow{3}{*}{ Ingredients } & \multicolumn{5}{|c|}{ Experimental diets } \\
\hline & \multicolumn{5}{|c|}{ Oregano essential oil $\left(\mathrm{g} \mathrm{kg}^{-1}\right)$} \\
\hline & $\mathbf{0}$ & 0.5 & 1.0 & 1.5 & 2.0 \\
\hline Soybean meal $^{1}$ & 443.84 & 443.84 & 443.84 & 443.84 & 443.84 \\
\hline Fish meal $^{1}$ & 289.71 & 289.71 & 289.71 & 289.71 & 289.71 \\
\hline Ground corn grain ${ }^{1}$ & 193.46 & 193.46 & 193.46 & 193.46 & 193.46 \\
\hline Wheat flour ${ }^{1}$ & 63.21 & 63.21 & 63.21 & 63.21 & 63.21 \\
\hline Wheat bran ${ }^{1}$ & 60.17 & 60.17 & 60.17 & 60.17 & 60.17 \\
\hline Vitamin-mineral premix ${ }^{3}$ & 10.00 & 10.00 & 10.00 & 10.00 & 10.00 \\
\hline Monocalcium phosphate & 10.00 & 10.00 & 10.00 & 10.00 & 10.00 \\
\hline Salt & 5.00 & 5.00 & 5.00 & 5.00 & 5.00 \\
\hline Soybean oil ${ }^{1}$ & 1.00 & 9.50 & 9.00 & 8.50 & 8.00 \\
\hline Oregano oil ${ }^{2}$ & 0 & 0.50 & 1.00 & 1.50 & 2.00 \\
\hline \multicolumn{6}{|c|}{ Chemical composition of diets } \\
\hline Dry matter $\left(\mathrm{g} \mathrm{kg}^{-1}\right)$ & 918.6 & 917.2 & 918.5 & 921.5 & 923.1 \\
\hline Crude protein $\left(\mathrm{g} \mathrm{kg}^{-1}\right)$ & 385.2 & 385.4 & 382.6 & 381.9 & 382.6 \\
\hline Lipid $\left(\mathrm{g} \mathrm{kg}^{-1}\right)$ & 64.1 & 71.5 & 66.6 & 62.5 & 60.4 \\
\hline Ashes $\left(\mathrm{g} \mathrm{kg}^{-1}\right)$ & 119.0 & 114.2 & 117.2 & 115.4 & 116.0 \\
\hline Digestible Energy $\left(\mathrm{Kcal} \mathrm{kg}^{-1}\right)$ & 3315 & 3315 & 3315 & 3315 & 3315 \\
\hline Carvacrol $\left(\mathrm{mg} \mathrm{kg}^{-1}\right)^{4}$ & 0 & 0.375 & 0.75 & 1.125 & 1.50 \\
\hline Thymol $\left(\mathrm{mg} \mathrm{kg}^{-1}\right)^{4}$ & 0 & 0.03 & 0.06 & 0.09 & 0.12 \\
\hline$\rho$-Cimene $\left(\mathrm{mg} \mathrm{kg}^{-1}\right)^{4}$ & 0 & 0.025 & 0.05 & 0.075 & 0.10 \\
\hline$\gamma$-Terpinene $\left(\mathrm{mg} \mathrm{kg}^{-1}\right)^{4}$ & 0 & 0.02 & 0.04 & 0.06 & 0.08 \\
\hline
\end{tabular}

${ }^{1}$ Biorgânica Comércio de Produtos Orgânicos Ltda., Realeza/PR.

${ }^{2}$ LASZLO Aromaterapia Ltda., Belo Horizonte/MG. (Composition: Carvacrol: 75-80\%; Thymol: 4-6\%; $\rho$-Cimene: 4-5\%; $\gamma$-Terpinene: 3-4\%; 1,8-Cineol: 1-2\%; Canfene: 1-2\%; Caryophyllene: 1-2\%; Felandrene: 1-2\%; Limonene: 1-2\%.

${ }^{3}$ Composition (units kg-1 of premix): vitamin A - 1,000,000 IU; vitamin D3 - 500,000 IU; vitamin E - 20,000 IU; vitamin K3 - 500 $\mathrm{mg}$; antioxidant - $0.6 \mathrm{~g}$; folic acid - $250 \mathrm{mg}$; pantothenic acid - $5000 \mathrm{mg}$; biotin - $125 \mathrm{mg}$; niacin - $5000 \mathrm{mg}$; thiamin - $1250 \mathrm{mg}$; cyanocobalamin - $3750 \mathrm{mg}$; riboflavin - $2500 \mathrm{mg}$; pyridoxine $2485 \mathrm{mg}$; ascorbic acid 42,000 mg; cobalt $25 \mathrm{mg}$; copper $2000 \mathrm{mg}$; iron 13,820 mg; iodine $100 \mathrm{mg}$; manganese $3750 \mathrm{mg}$; selenium $75 \mathrm{mg}$ and zinc 17,500 mg.

${ }^{4}$ Values calculated according to the chemical composition of oregano essential oil presented by the manufacturer.

The photoperiod was 12 hours light. The water temperature and salinity (monitored daily) remained at $28.3 \pm 0.97{ }^{\circ} \mathrm{C}$ and $3.1 \pm 0.64 \%$, respectively. Levels of $\mathrm{pH}$, ammonia, and nitrite (monitored weekly) were maintained at $7 \pm 0.04,0.021 \pm$ $0.009 \mathrm{mg} \mathrm{L}^{-1}$, and $0.4 \pm 0.08 \mathrm{mg} \mathrm{L}^{-1}$, respectively. Dissolved oxygen concentrations, hardness, and alkalinity (monitored fortnightly) were $8.84 \pm 0.66$ $\mathrm{mg} \mathrm{L}^{-1}, 86.67 \pm 40.33 \mathrm{mg} \mathrm{L}^{-1}$, and $31.67 \pm 11.69 \mathrm{mg}$ $\mathrm{L}^{-1}$, respectively. All water quality parameters were within tolerable conditions for the species (GOMES et al., 2000).

At the end of the feeding period, the fish were anesthetized ( $1 \mathrm{~mL}$ clove oil $10 \mathrm{~L}^{-1}$ water), counted and weighed individually for survival and growth assessment. After biometry, seven silver catfish were placed in their respective tanks, which were disconnected from the recirculation system to perform the experimental infection with $I$. multifilliis. 


\section{Experimental diets}

Five isoproteic (37\% crude protein - CP) and isoenergetic $(3,315 \mathrm{Kcal}$ digestible energy - DE $\mathrm{kg}^{-1}$ ) pelleted diets were formulated to meet the nutritional requirements of silver catfish (RADÜNZ NETO; BORBA, 2012). The basal composition of the diets was fish and soybean meals, as protein ingredients; corn, wheat, and certified organic soybean oil, as energetic ingredients; salt; mineralvitamin premix; and essential oil of oregano $\left(\right.$ LASZLO $\left.^{\circledR}\right)$ as an additive. Treatments consisted of five supplementary doses of this oil: 0.5, 1.0, 1.5, and $2.0 \mathrm{~g} \mathrm{~kg}^{-1}$ (FERREIRA et al., 2014), besides a control $\left(0 \mathrm{~g} \mathrm{~kg}^{-1}\right)$, with four replicates (Table 1). All dry ingredients were milled and sieved $(<600 \mu)$ to standardize the particle diameter. The oregano essential oil was mixed with soybean oil and then homogenized to the other ingredients. The diets were prepared by initially blending the dry ingredients, then adding the oil, and finally water. The resulting homogeneous mass was passed through a $3-\mathrm{mm}$ mesh matrix and the filaments produced were oven dried at $40{ }^{\circ} \mathrm{C}$. After drying, the diets were packed in hermetically sealed plastic bags and stored at $-20^{\circ} \mathrm{C}$ until use. To avoid frequent handling of frozen diets, sufficient quantities for one week were stored in plastic bottles and kept under refrigeration $\left(4{ }^{\circ} \mathrm{C}\right)$. The centesimal composition of the diets was determined according to procedures of the Association of Official Analytical Chemists (AOAC, 2000).

Growth assessment and hematological analysis of fish

The fish from each experimental unit, after 15 hours fasting, were anesthetized and weighed in groups every twenty days and individually at the end of the experiment. Samples of 20 silver catfish from the initial stock and 3 silver catfish per tank ( $\mathrm{n}$ $=12$ ) at the end of the experiment were collected to determine the body composition of the whole fish (AOAC, 2000). The fish were sacrificed by medullary section and stored $\left(-20^{\circ} \mathrm{C}\right)$ until analysis. The livers and viscera of the other three silver catfish per tank $(\mathrm{n}=12)$ were removed and weighed to determine respectively the hepatosomatic index (HSI) and viscerosomatic index (VSI), besides carcass yield. For the hematological analysis, blood samples were obtained by caudal vein puncture of two fish per tank $(n=8)$. The procedures used in this study were in accordance with the Ethics Committee for Animal Use (CEUA) - UFFS, Protocol No. 23205.002276 / 2015-16.

The performance of silver catfish juveniles was evaluated considering the following parameters: Survival $-S=$ (final number of fish / initial number of fish) $x$ 100; Weight gain $-\mathrm{WG}=$ (final weight - initial weight); Daily feed consumption (\% body weight day $\left.{ }^{-1}\right)-D F C=$ [feed intake (dry matter)/ (final weight + initial weight/2)]/time in days $\times 100$; Feed conversion $-F C=$ (feed intake (dry matter) weight gain); Specific growth rate $-S G R=[(\ln$ final weight - In initial weight)/days of experiment] $x$ 100; Protein efficiency ratio - PER = (weight gain/protein intake (dry matter)); Hepatosomatic index: $H S I=($ liver weight/whole body weight) $x$ 100; Viscerosomatic index: VSI = (viscera weight) whole body weight) $x 100$; and Carcass yield: $C Y=$ (carcass weight/final weight) $x 100$.

For the hematological analysis, at the end of the 89 days of the feeding period, blood was collected from two silver catfish juveniles per experimental unit $(\mathrm{n}=8)$ using syringes washed internally with 10\% EDTA solution. The absolute hematimetric indexes and their variables, differential leukocyte count, total leukocyte count, thrombocytes and respiratory burst were evaluated. The erythrocyte count was carried out in a Newbauer hemocytometric chamber using diluent according to Natt and Herrick (1952). Hemoglobin concentration was assessed according to the cyanometa-hemoglobin method (BLAXHALL; DAISLEY, 1973). The hematocrit was determined using microhematocrit according to the methodology recommended by Goldenfarb et al. (1971). The hematimetric 
variables, Mean Corpuscular Volume (MCV), Mean Corpuscular Hemoglobin (MCH) and Mean Corpuscular Hemoglobin Concentration (MCHC) were determined according to the method of Wintrobe (1934), where: $M C V(f L)=$ [(hematocrit No. $\times 10) /$ No. of erythrocytes]; $M C H\left(\right.$ p cell $\left.^{-1}\right)=$ [(Hemoglobin x 10) / No. of erythrocytes]; MCHC $\left(g d L^{-1}\right)=[($ Hemoglobin $\times 100) /$ Hematocrit $]$. The total count of leukocytes and thrombocytes was carried out by the indirect method (TAVARESDIAS et al., 2002): Leukocytes $\left(10^{6} \mu \mathrm{L}^{-1}\right)=[(\mathrm{No}$. of leukocytes $x$ total No. of erythrocytes)/2000 erythrocytes counted in the blood]; Thrombocytes $\left(\mu \mathrm{L}^{-1}\right)=[$ No. of thrombocytes $x$ total No. of erythrocytes)/2000 erythrocytes counted in the blood]. For the differential count of defense cells (leukocytes), blood smears were stained according to the Rosenfeld (1947), where 100 cells were counted in each slide and the result expressed in $\%$ of each cell type (neutrophil, lymphocyte, monocyte, eosinophil and special granulocytic cell). Then the absolute number of each was calculated with respect to the total number of leukocytes observed in the Newbauer chamber. The respiratory burst of leukocytes was determined following the protocol of Anderson and Siwicki (1995), which consists of a colorimetric determination of the ROS (reactive oxygen species) produced by the respiratory burst of leukocytes.

\section{Experimental infection - determination of infection level and accumulated mortality}

Silver catfish juveniles, naturally infected with ich, were kept in an isolated tank in the laboratory, serving as initial inoculum for the experimental infection. The ich challenge followed different steps: 1 - collection of trophonts by gentle scraping with a scalpel blade on the body surface of ich infected silver catfish; 2 - deposition of this collected material into a Petri dish by scalpel blade washing with dechlorinated water jets, being then incubated for 24 hours for theronts (infectious form) to be inoculated in each experimental unit; 3 - these theronts were then transferred to a $30-\mathrm{mL}$ Becker flask, counted in triplicate with the aid of a Sedgewick-Rafter chamber (theronts $\mathrm{mL}^{-1}$ ); then, 21,000 theronts were inoculated per fish (XU et al., 2004). The proper number of theronts for each experimental unit $(147,000)$ was placed in Petri dishes, which were subsequently dipped into the tanks. In order to have a higher probability of the parasite-host encounter, the water volume of the tanks was reduced to $15 \mathrm{~L}$ in the first hour of ich infection and the volume (54 L) was restored later. One replicate of each treatment was not inoculated with ich and served as a negative control of the infection.

During the period of experimental infection, fish were fed only once a day to avoid deterioration of water quality. Moreover, in order to minimize the risk of modifying the quantity of inoculum in the tanks because of the eventual removal of parasites via siphoning and water exchange, $30 \%$ of the water volume was renewed every two days. Temperature, concentrations of dissolved oxygen, and ammonia in the water during infection period were, respectively, $19.02 \pm 0.72{ }^{\circ} \mathrm{C}, 7.5 \pm 0.5 \mathrm{mg} \mathrm{L}^{-1}$ and $0.1 \pm 0.0 \mathrm{mg}$ $\mathrm{L}^{-1}$.

After 5 days of challenge, samples of three fish were collected per experimental unit $(n=12)$, which were sacrificed by medullary section and preserved in $4 \%$ formaldehyde to determine the level of ich infection. The remaining fish were kept in each tank to observe the evolution of accumulated mortality. The number of trophonts (white spots) on the body surface of the silver catfish, including caudal, anal, adipose, dorsal, pectoral, and pelvic fins were counted using a magnifying glass. The number of trophonts in each fish was determined by the mean between two counts performed with a variation of less than 10\% (BORBA et al., 2007). 


\section{Statistical analysis}

The evaluation of the effects of dietary oregano essential oil concentrations on the parameters of performance and resistance to ich infection in silver catfish juveniles was carried out through one-way ANOVA and polynomial regression. To verify the normality and homoscedasticity of the data the Shapiro Wilk test was applied. All analyses were carried out with the aid of software $\mathrm{R}$, adopting the 5\% significance level. Percentage values were sinarc transformed for analysis (ZAR, 1996).

\section{Results and Discussion}

No effect $(\mathrm{p}>0.05)$ of dietary oregano essential oil concentrations $\left(0.5,1.0,1.5\right.$ and $\left.2.0 \mathrm{~g} \mathrm{~kg}^{-1}\right)$ was observed on the performance variables analyzed (Table 2).
Silver catfish juveniles fed actively during the experiment, showing an increase in weight of about 5.3-fold after 89 days of experiment. Feed conversion (1.40 to 1.56$)$ and specific growth rate (1.62 to $1.89 \%$ ) were slightly worse than mean values of FC (1.3) and SGR (2.3\%) presented by juveniles of $R$. quelen with initial weight of 14.5 $\mathrm{g}$, fed different dietary levels of linseed for seven weeks (GOULART et al., 2013). However, the inferior results verified here might be related to a longer experimental period, which was almost twice longer than that of the aforementioned study. In addition, SGR values $<1.0 \%$ for $R$. quelen, lower than those obtained in the present study, were found in the literature, even though they were fish with lower initial weight (2.9 g) and shorter experimental period (45 days) (ROCHA et al., 2007). According to Losekann et al. (2008), FC values between 1.31.5 are considered acceptable for silver catfish.

Table 2. Zootechnical performance of silver catfish juveniles fed diets containing different concentrations of oregano essential oil for 89 days ${ }^{1}$.

\begin{tabular}{lccccc}
\hline & \multicolumn{5}{c}{ Experimental diets } \\
\cline { 2 - 6 } Zootechnical performance & \multicolumn{5}{c}{ Oregano essential oil $\left(\mathbf{g ~ k g}^{-1}\right)$} \\
\cline { 2 - 6 } & $\mathbf{0}$ & $\mathbf{0 . 5}$ & $\mathbf{1 . 0}$ & $\mathbf{1 . 5}$ & $\mathbf{2 . 0}$ \\
\hline Survival (\%) & $98.75 \pm 0.5$ & $93.75 \pm 6.29$ & $95.00 \pm 7.07$ & $98.75 \pm 2.5$ & $100.0 \pm 0.0$ \\
Weight gain (g) & $53.22 \pm 6.59$ & $50.82 \pm 4.99$ & $53.13 \pm 5.22$ & $50.21 \pm 9.93$ & $48.87 \pm 1.58$ \\
Specific growth rate (\%) & $1.89 \pm 0.11$ & $1.85 \pm 0.09$ & $1.69 \pm 0.08$ & $1.63 \pm 0.16$ & $1.62 \pm 0.03$ \\
Daily food consumption (\% body weight / day) & $2.32 \pm 0.14$ & $2.30 \pm 0.07$ & $2.15 \pm 0.08$ & $2.22 \pm 0.12$ & $2.34 \pm 0.08$ \\
Food conversion & $1.50 \pm 0.12$ & $1.51 \pm 0.06$ & $1.40 \pm 0.09$ & $1.48 \pm 0.06$ & $1.56 \pm 0.06$ \\
Protein efficiency ratio & $1.73 \pm 0.13$ & $1.72 \pm 0.06$ & $1.88 \pm 0.13$ & $1.77 \pm 0.08$ & $1.68 \pm 0.06$ \\
Hepatosomatic index (\%) & $1.26 \pm 0.09$ & $1.20 \pm 0.22$ & $1.34 \pm 0.14$ & $1.28 \pm 0.11$ & $1.43 \pm 0.11$ \\
Viscerosomatic index (\%) & $8.91 \pm 0.23$ & $9.43 \pm 1.35$ & $9.47 \pm 0.61$ & $10.25 \pm 1.01$ & $8.79 \pm 0.96$ \\
Carcass yield (\%) & $89.83 \pm 0.21$ & $89.36 \pm 1.42$ & $89.19 \pm 0.67$ & $88.46 \pm 1.09$ & $89.79 \pm 0.96$ \\
ANOVA $P$ & $\mathrm{~ns}$ & $\mathrm{~ns}$ & $\mathrm{~ns}$ & $\mathrm{~ns}$ & $\mathrm{~ns}$ \\
Regression $P$ & $\mathrm{~ns}$ & $\mathrm{~ns}$ & $\mathrm{~ns}$ & $\mathrm{~ns}$ & $\mathrm{~ns}$ \\
\hline
\end{tabular}

${ }^{1}$ Initial fish weight $=12 \pm 0.5 \mathrm{~g}$ (mean \pm standard deviation).

${ }^{2}$ Non-significant $(\mathrm{p}>0.05)$. 
The protein efficiency ratio was quite similar among dietary treatments (1.7 to 1.9), suggesting a good use of dietary protein. Similar values were obtained in a study with juveniles of $R$. quelen with $15 \mathrm{~g}$ of initial weight, fed different protein sources for 60 days (LAZZARI et al., 2006).

The hepatosomatic (HSI) and viscerosomatic (VSI) indexes and the carcass yield (CY) showed no significant variation, indicating the lack of morphological changes in relation to the diets tested (LOVATTO et al., 2014). In studies with silver catfish juveniles of similar size, no significant differences were observed for these parameters either, but higher mean values of HSI (1.5 to $1.7 \%$ ) and lower CY (84.3 to $86.4 \%$ ) were obtained by Lovatto et al. (2014) and Goulart et al. (2013), respectively.

In the literature, there is little information about the influence of oregano essential oil addition into fish diets, which in turn are somewhat conflicting. Corroborating with the present study, Kanashiro (2015) also found no significant effect on the performance parameters evaluated when studying juveniles of yellowtail tetra, Astyanax lacustres (= A. altiparanae $)$ fed diets supplemented with oregano essential oil. Likewise, no effect was observed on growth parameters in juveniles of Nile tilapia (Oreochromis niloticus) fed different essential oils, including oregano essential oil (CAMPAGNOLO et al., 2013). As well as there was no significant influence on the results in studies using supplementation with carvacrol (main active ingredient of oregano essential oil) in diets for O. niloticus (FRECCIA et al., 2014), sea bass (Dicentrarchus labrax) (VOLPATTI et al., 2014) and rainbow trout (Oncorhynchus mykiss) (YILMAZ et al., 2015). On the other hand, in contrast to the aforementioned studies, the inclusion of oregano essential oil in the diet resulted in positive effects on the performance of juvenile channel catfish (Ictalurus punctatus) (ZHENG et al., 2009), of O. mykiss (AHMADIFAR et al., 2011; DILER et al., 2017), and of A. lacustres (=A. altiparanae) (FERREIRA et al., 2014).

Moreover, the different concentrations of oregano essential oil in the diet had no influence on the levels of fish moisture, protein, lipid, and ashes at the end of the 89 days of the feeding period (Table 3). Likewise, Yilmaz et al. (2015) found no significant differences in the body composition of O. mykiss juveniles fed carvacrol-supplemented diets. Conversely, other studies have demonstrated the influence of dietary supplementation with oregano essential oil, or its active ingredients, on the body composition of different fish species. In juveniles of I. punctatus, dietary supplementation with oregano essential oil, thymol, or carvacrol had no influence on the contents of lipid, ashes, and dry matter; whereas body protein levels were raised (ZHENG et al., 2009). In O. mykiss juveniles, dietary supplementation with thymol-carvacrol (1 to $3 \mathrm{~g} \mathrm{~kg}^{-1}$ ) had a significant influence on lipid, protein, and ash contents, but not on dry matter (AHMADIFAR et al., 2011). As for A. lacustres (= A. altiparanae) juveniles, only the ash content was not influenced by dietary treatments, the body protein increased significantly in fish fed diets with $2.5 \mathrm{~g} \mathrm{~kg}^{-1}$ of oregano essential oil, and there was a linear decreasing effect for dry matter and body lipid (FERREIRA et al., 2014). 
Table 3. Body composition of silver catfish juveniles fed diets containing different concentrations of oregano essential oil for 89 days ${ }^{1,2}$.

\begin{tabular}{|c|c|c|c|c|c|}
\hline \multirow{3}{*}{$\begin{array}{r}\text { Body composition } \\
(\%)\end{array}$} & \multicolumn{5}{|c|}{ Experimental diets } \\
\hline & \multicolumn{5}{|c|}{ Oregano essential oil $\left(\mathrm{g} \mathrm{kg}^{-1}\right)$} \\
\hline & $\mathbf{0}$ & 0.5 & 1.0 & 1.5 & 2.0 \\
\hline Moisture & $68.35 \pm 0.69$ & $68.31 \pm 0.66$ & $69.73 \pm 1.16$ & $69.31 \pm 0.23$ & $68.98 \pm 0.73$ \\
\hline Protein & $17.22 \pm 0.51$ & $17.53 \pm 0.36$ & $17.91 \pm 0.66$ & $17.61 \pm 0.96$ & $18.03 \pm 0.47$ \\
\hline Lipid & $11.75 \pm 0.81$ & $11.78 \pm 0.92$ & $10.96 \pm 1.10$ & $11.50 \pm 0.37$ & $11.12 \pm 1.30$ \\
\hline Ash & $3.01 \pm 0.27$ & $3.08 \pm 0.13$ & $2.95 \pm 0.22$ & $2.95 \pm 0.34$ & $2.94 \pm 0.17$ \\
\hline ANOVA $P$ & $\mathrm{~ns}^{3}$ & $\mathrm{~ns}$ & $\mathrm{~ns}$ & $\mathrm{~ns}$ & ns \\
\hline Regression $P$ & ns & ns & $\mathrm{ns}$ & $\mathrm{ns}$ & $\mathrm{ns}$ \\
\hline
\end{tabular}

${ }^{1}$ Initial body composition (\%): moisture 75.51; Protein, lipid and ash (wet basis): 16.97; 5.12; 3.46, respectively.

${ }^{2}$ Mean \pm SD of pooled samples of three fish from each of four replicate groups $(n=12)$.

${ }^{3}$ Non-significant $(\mathrm{p}>0.05)$.

The level of inclusion of oregano essential oil in the diet, as well as the composition and concentration of the bioactive compounds, may be factors of variation in the results of studies carried out with this type of natural additive. Nonetheless, these might not have been the reasons for the non-significant differences among treatments found in the present study, as the same commercial product and the same concentrations were evaluated by Ferreira et al. (2014) and they obtained significant improvement in the performance and body composition of juveniles of $A$. lacustres ( $=A$. altiparanae). Other factors may also influence the results obtained with this additive, such as the time of administration, the development phase of the fish and the intrinsic characteristics of each species (CAMPAGNOLO et al., 2013; YILMAZ et al., 2015).

The presence, number, and proportion of blood cells reflect the physiological state of the animal and are important tools for assessing fish health (SADO et al., 2014). In the present study, no significant changes were observed in the hematological and immunological parameters of silver catfish juveniles fed increasing levels of oregano essential oil in the diet (Table 4). Likewise, dietary supplementation with carvacrol had no influence on hematological parameters in juveniles of $O$. mykiss (YILMAZ et al., 2015).

The hematological and the leukocytes variables, and the hematimetric indexes of silver catfish juveniles were within the basal values found for the species (TAVARES-DIAS et al., 2002), indicating the suitability of the environment for the fish during the experimental period, with acceptable water quality parameters for the species (GOMES et al., 2000). The non-alteration of these variables in the present study suggests, according to Tavares-Dias et al. (2007), the lack of significant stressors affecting the fish and their adequate nutritional state. 
Table 4. Hematological parameters (erythrocytes and defense cells) of silver catfish juveniles fed diets containing different concentrations of oregano essential oil for 89 days.

\begin{tabular}{|c|c|c|c|c|c|}
\hline \multirow{3}{*}{$\begin{array}{c}\text { Hematological } \\
\text { parameters }\end{array}$} & \multicolumn{5}{|c|}{ Experimental diets } \\
\hline & \multicolumn{5}{|c|}{ Oregano essential oil $\left(\mathrm{g} \mathrm{kg}^{-1}\right)$} \\
\hline & $\mathbf{0}$ & 0.5 & 1.0 & 1.5 & 2.0 \\
\hline Erythrocytes $\left(10^{6} \mu \mathrm{L}^{-1}\right)$ & $\begin{array}{c}2.758 \times 10^{6} \pm \\
0.412 \times 10^{6}\end{array}$ & $\begin{array}{c}.046 \times 10^{6} \pm \\
0.758 \times 10^{6}\end{array}$ & $\begin{array}{c}2.816 \times 10^{6} \pm \\
0.696 \times 10^{6}\end{array}$ & $\begin{array}{c}2.483 \times 10^{6} \pm \\
0.427 \times 10^{6}\end{array}$ & $\begin{array}{c}2.714 \times 10^{6} \pm \\
0.302 \times 10^{6}\end{array}$ \\
\hline Hematocrit (\%) & $22.57 \pm 1.72$ & $25.38 \pm 4.63$ & $23.13 \pm 4.09$ & $19.88 \pm 3.91$ & $22.38 \pm 2.13$ \\
\hline $\operatorname{MCV}(f \mathrm{~L})$ & $84.83 \pm 11.97$ & $84.93 \pm 11.64$ & $84.46 \pm 16.35$ & $81.08 \pm 16.91$ & $83.11 \pm 10.37$ \\
\hline HB conc. $\left(\mathrm{g} \mathrm{dL}^{-1}\right)$ & $6.33 \pm 1.13$ & $6.32 \pm 2.47$ & $6.30 \pm 1.73$ & $4.89 \pm 1.80$ & $5.52 \pm 1.79$ \\
\hline $\mathrm{MCH}\left(\mathrm{pg} \mathrm{cel}^{-1}\right)$ & $24.11 \pm 3.74$ & $21.41 \pm 9.45$ & $22.62 \pm 4.76$ & $20.68 \pm 10.57$ & $20.11 \pm 5.05$ \\
\hline $\operatorname{MCHC}\left(\mathrm{g} \mathrm{dL}^{-1}\right)$ & $28.74 \pm 4.69$ & $25.09 \pm 9.84$ & $27.37 \pm 6.85$ & $26.77 \pm 15.03$ & $24.55 \pm 6.98$ \\
\hline Thrombocytes $\left(\mu \mathrm{L}^{-1}\right)$ & $\begin{array}{c}63687.04 \pm \\
40842.83\end{array}$ & $\begin{array}{c}41012.27 \pm \\
21108.07\end{array}$ & $\begin{array}{c}37905.65 \pm \\
22076.91\end{array}$ & $\begin{array}{c}42132.95 \pm \\
11315.77\end{array}$ & $\begin{array}{c}41932.71 \pm \\
22415.31\end{array}$ \\
\hline Total Leukocytes $\left(\mu \mathrm{L}^{-1}\right)$ & $\begin{array}{c}37273.63 \pm \\
17710.17\end{array}$ & $\begin{array}{c}28259.08 \pm \\
13800.34\end{array}$ & $\begin{array}{c}31616.54 \pm \\
9644.50\end{array}$ & $\begin{array}{c}35185.86 \pm \\
26288.86\end{array}$ & $\begin{array}{c}32106.81 \pm \\
10945.69\end{array}$ \\
\hline Lymphocytes $\left(\mu \mathrm{L}^{-1}\right)$ & $\begin{array}{c}18230.56 \pm \\
6579.53\end{array}$ & $\begin{array}{c}16914.80 \pm \\
8508.69\end{array}$ & $\begin{array}{c}16134.00 \pm \\
6398.07\end{array}$ & $\begin{array}{c}17439.05 \pm \\
18820.17\end{array}$ & $\begin{array}{c}1583.43 \pm \\
6146.22\end{array}$ \\
\hline Neutrophils $\left(\mu \mathrm{L}^{-1}\right)$ & $\begin{array}{c}16392.20 \pm \\
13760.63\end{array}$ & $\begin{array}{c}9667.11 \pm \\
5979.25\end{array}$ & $\begin{array}{c}13909.42 \pm \\
8366.28\end{array}$ & $\begin{array}{c}14326.37 \pm \\
8309.10\end{array}$ & $\begin{array}{c}13757.14 \pm \\
6640.57\end{array}$ \\
\hline Monocytes $\left(\mu \mathrm{L}^{-1}\right)$ & $\begin{array}{c}2323.37 \pm \\
978.10\end{array}$ & $\begin{array}{c}1196.19 \pm \\
1242.66\end{array}$ & $\begin{array}{c}1236.64 \pm \\
480.38\end{array}$ & $\begin{array}{c}2828.98 \pm \\
2449.47\end{array}$ & $\begin{array}{c}2083.68 \pm \\
806.85\end{array}$ \\
\hline Eosinophils $\left(\mu \mathrm{L}^{-1}\right)$ & $\begin{array}{c}19.81 \pm \\
56.04\end{array}$ & $\begin{array}{c}207.38 \pm \\
249.40\end{array}$ & $\begin{array}{c}185.98 \pm \\
185.39\end{array}$ & $\begin{array}{c}277.71 \pm \\
370.39\end{array}$ & $\begin{array}{c}27.45 \pm \\
53.68\end{array}$ \\
\hline $\operatorname{SGC}\left(\mu \mathrm{L}^{-1}\right)$ & $\begin{array}{c}307.64 \pm \\
381.57\end{array}$ & $\begin{array}{c}273.60 \pm \\
336.21\end{array}$ & $\begin{array}{c}150.51 \pm \\
167.98\end{array}$ & $\begin{array}{c}313.75 \pm \\
416.21\end{array}$ & $\begin{array}{c}407.11 \pm \\
475.42\end{array}$ \\
\hline Burst (OD) & $\begin{array}{c}0.275 \pm \\
0.100\end{array}$ & $\begin{array}{c}0.316 \pm \\
0.103\end{array}$ & $\begin{array}{c}0.395 \pm \\
0.073\end{array}$ & $\begin{array}{c}0.328 \pm \\
0.087\end{array}$ & $\begin{array}{c}0.280 \pm \\
0.108\end{array}$ \\
\hline ANOVA $P$ & $\mathrm{~ns}^{1}$ & ns & ns & ns & ns \\
\hline Regression $P$ & ns & ns & ns & $\mathrm{ns}$ & $\mathrm{ns}$ \\
\hline
\end{tabular}

MCV (Mean Corpuscular Volume); HB conc. (Hemoglobin Concentration); MCH (Mean Corpuscular Hemoglobin); MCHC (Mean Corpuscular Hemoglobin Concentration); SGC (Special Granulocytic Cell); OD (Optical Density).

${ }^{1}$ Non-significant $(\mathrm{p}>0.05)$.

Essential oils are considered biological substances with an immunostimulating capacity in vertebrates against infectious agents (HARIKRISHNAN et al., 2011; JENEY et al., 2009). However, such positive effects are not always verified and, as in the present study, Volpatti et al. (2014) observed no influence of dietary supplementation with carvacrol on D. labrax juvenile defense cells. On the other hand, Ahmadifar et al. (2011) found that O. mykiss juveniles fed diets containing thymol-carvacrol presented a higher number of lymphocytes than the control group.
Similarly, in a study also with juveniles of $O$. mykiss fed diets containing increasing levels of oregano essential oil, both great lysozyme activity and disease resistance were observed in fish receiving the highest level tested $\left(3 \mathrm{~mL} \mathrm{~kg}^{-1}\right)$ (DILER et al., 2017). It is worth highlighting the current scarcity of studies concerning the effects of essential oils on fish immune system, especially for Neotropical species, and nonexistent in agroecological systems of production. However, they are an important tool for better understanding of the mechanisms of action 
of these substances (TAVARES-DIAS et al., 2009).

The ineffective action of oregano essential oil in diets for silver catfish juveniles as an immunostimulatory of the defense cells might have been due to the lack of exposure to pathogen during the 89 days of the feeding period. Therefore, once the fish immune system has not been activated, leukocyte number showed no differences among treatments. Nor did the respiratory burst activity show any stimulation of the phagocytic cells. In contrast, some reports in the literature have shown that even when in the presence of a pathogen the defense cell stimulus is not evidenced. This was the case of juveniles of Diplodus puntazzo, a sea fish species, fed oregano essential oil; these fish presented no greater number of phagocytic cells and no respiratory burst activity even when infected by Myxobolus sp. (KARAGOUNI et al., 2005).

The inclusion of increasing levels of oregano essential oil in the diet did not present an immunostimulatory effect for silver catfish juveniles, which could be confirmed by hematological analysis and resistance to challenge with ectoparasite $I$. multifiliis. All treatments showed high level of ich infection and significant mortality rates (Table 5 and Figure 1, respectively), with 100\% fish mortality between the 11 and 13th days of experimental infection. After the onset of fish deaths, the release of theronts occurs exponentially and there is a process of re-infection of the animals, which raises the cumulative mortality (YASUMARU, 2007).

In juveniles of $O$. mykiss fed diets containing different levels of vitamin $\mathrm{C}$ for 8 weeks, no difference in infection level of fish collected 8 days after experimental infection with ich was observed. However, cumulative mortality was significantly lower in diets with higher vitamin $\mathrm{C}$ concentrations compared to lower concentrations and control diet, suggesting a better general condition of the fish (WAHLI et al., 1995). In a study with silver catfish juveniles, also fed diets supplemented with different levels of vitamin $\mathrm{C}$ and later challenged with ich, there was no significant difference among the treatments, even in relation to the fish fed the control diet, free of vitamin C (BORBA et al., 2007).

Table 5. Mean infection levels in silver catfish juveniles fed diets containing different concentrations of oregano essential oil for 89 days and challenged with Ichthyophthirius multifiliis ${ }^{1}$.

\begin{tabular}{cc}
\hline $\begin{array}{c}\text { Diets } \\
\text { (Oregano essential oil, } \mathbf{g ~ k g}^{-1} \text { ) }\end{array}$ & $\begin{array}{c}\text { Level of infection } \\
\text { (Number of trophonts per fish) }\end{array}$ \\
\hline 0 & $265.44 \pm 49.86$ \\
0.5 & $348.22 \pm 300.16$ \\
1.0 & $331.67 \pm 288.38$ \\
1.5 & $284.44 \pm 168.12$ \\
2.0 & $369.67 \pm 120.58$ \\
ANOVA $P$ & $\mathrm{~ns}^{2}$ \\
Regression $P$ & $\mathrm{~ns}$ \\
\hline
\end{tabular}

${ }^{1}$ Mean \pm SD of samples composed of three fish from each replicate $(n=9)$.

${ }^{2}$ Non-significant $(\mathrm{p}>0.05)$. 
Figure 1. Cumulative mortality ${ }^{1}$ of silver catfish juveniles fed diets containing different concentrations of oregano essential oil for 89 days and challenged with Ichthyophthirius multifiliis.

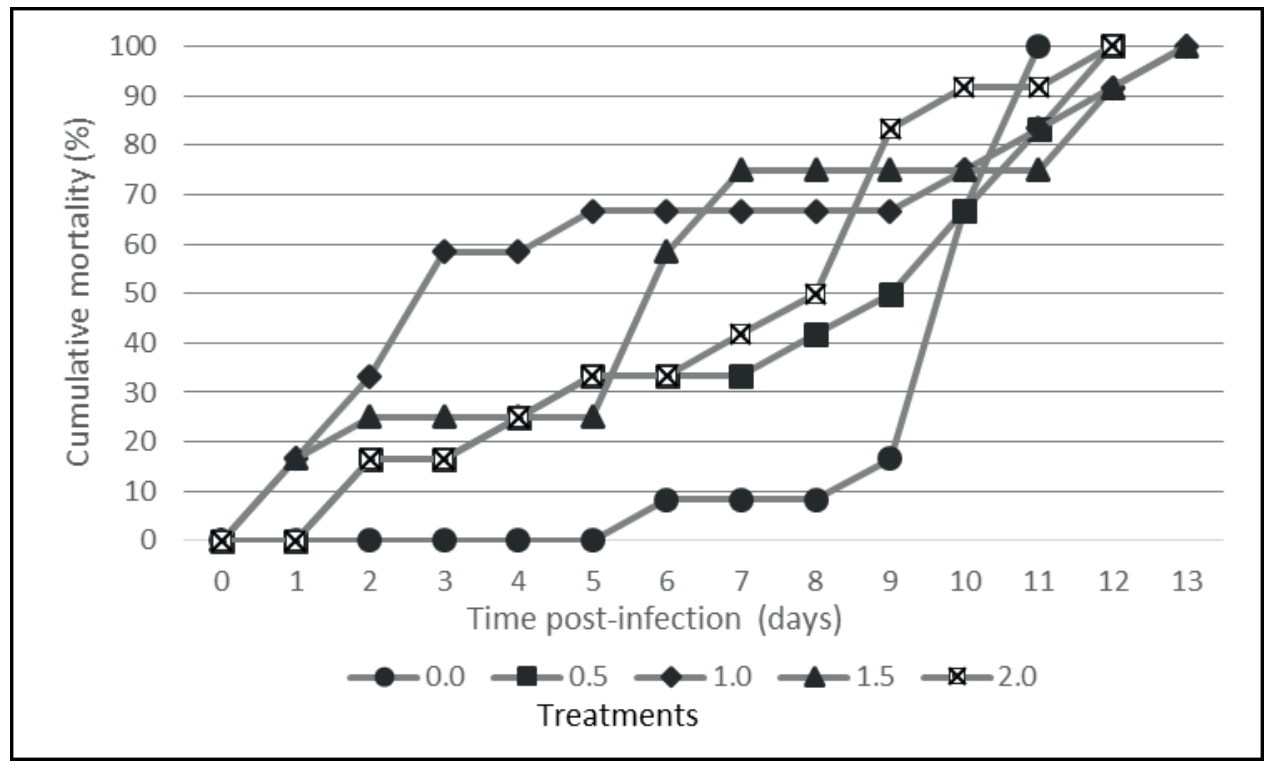

${ }^{1}$ Non-significant $(\mathrm{p}>0.05)$.

\section{Conclusion}

Dietary supplementation with oregano essential oil did not prove to be effective in improving the zootechnical performance or increasing the resistance of silver catfish juveniles to I. multifiliis. However, in view of the importance of the topic, further studies should be carried out to increase knowledge about the mechanisms of action and effect of this and other natural additives on silver catfish, even at other stages of development.

\section{References}

ABBAS, A. A.; EL-ASELY, A. M.; KANDIEL, M. M. M. Effects of dietary propolis and pollen on growth performance, fecundity and some hematological parameters of Oreochromis niloticus. Turkish Journal of Fisheries and Aquatic Sciences, Trabzon, v. 12, n. 4, p. 851-859, 2012.

AHMADIFAR, E.; FALAHATKAR, B.; AKRAMI, R. Effects of dietary thymol-carvacrol on growth performance, hematological parameters and tissue composition of juvenile rainbow trout, Oncorhynchus mykiss. Journal of Applied Ichthyology, Verlag, v. 27, n. 4, p. 1057-1060, 2011.

ANDERSON, D. P.; SIWICKI, A. K. Basic haematology and serology for fish health programs. In: SHARIFF, M.; ARTHUR, J. R.; SUBASINGHE, R. P. (Ed.). Diseases in Asian aquaculture II. Fish health section. Manila: Asian Fisheries Society, 1995. p. 185-202.

ASSOCIATION OF OFFICIAL ANALYTICAL CHEMISTS - AOAC. Official methods of analysis. $16^{\text {th }}$ ed. Gaithersburg: AOAC, 2000. 1141 p.

BALDISSEROTTO, B.; RADÜNZ NETO, J. Jundiá (Rhamdia sp.). In: BALDISSEROTTO, B.; GOMES, C. L. Espécies nativas para piscicultura no Brasil. Santa Maria: UFSM, 2005. p. 303-319.

BLAXHALL, P. C.; DAISLEY, K. W. Routine hematological methods for use with fish blood. Journal of Fish Biology, Medford, v. 5, n. 6, p. 771-781, 1973.

BORBA, M. R.; FRACALOSSI, D. M.; FREITAS, F. A. Efeito da suplementação de vitamina $\mathrm{C}$ na dieta sobre a susceptibilidade de alevinos de jundiá, Rhamdia quelen, ao Ichthyophthirius multifiliis. Acta Scientiarum. Animal Sciences, Maringá, v. 29, n. 1, p. 93-99, 2007.

BOSCOLO, W. R.; FEIDEN, A.; NEU, D. H.; DIETERICH, F. Sistema orgânico de produção de pescado de água doce. Revista Brasileira de Saúde e 
Produção Animal, Salvador, v. 13, n. 2, p. 578-590, 2012.

BRASIL. Ministério da Agricultura Pecuária e Abastecimento - MAPA e Ministério de Pesca e Aquicultura - MPA. Instrução Normativa Interministerial $\mathrm{n}^{\circ}$ 28, 08 de junho de 2011. Brasília: MAPA/MPA, 2011. 29 p. Disponível em: <http://www.mapa.gov.br/ legislação>. Acesso em: 15 set. 2015.

CAMPAGNOLO, R.; FRECCIA, A.; BERGMANN, R. R.; MEURER, F.; BOMBARDELLI, R. A. Óleos essenciais na alimentação de alevinos de tilápia do Nilo. Revista Brasileira de Saúde e Produção Animal, Salvador, v. 14, n. 3, p. 565-573, 2013.

CHAVES, A. V.; DUGAN, M. E. R.; STANFORD, K.; GIBSON, L. L.; BYSTROM, J. M.; MCALLISTER, T. A.; VAN HERK, F.; BENCHAAR, C. A dose-response of cinnamaldehyde supplementation on intake, ruminal fermentation, blood metabolites, growth performance, and carcass characteristics of growing lambs. Livestock Science, Amsterdam, v. 141, n. 2-3, p. 213-220, 2011.

DILER, O.; GORMEZ, O.; DILER, I.; METIN, S. Effect of oregano (Origanum onites L.) essential oil on growth, lysozyme and antioxidant activity and resistance against Lactococcus garvieae in rainbow trout, Oncorhynchus mykiss (Walbaum). Aquaculture Nutrition, New Jersey, v. 23, n. 4, p. 844-851, 2017.

FERREIRA, P. M. F.; NASCIMENTO, L. S.; DIAS, D. C.; MOREIRA, D. M. V.; SALARO, A. L.; FREITAS, M. B. D.; CARNEIRO, A. P. S.; ZUANON, J. A. S. Essential oregano oil as a growth promoter for the yellowtail tetra, Astyanax altiparanae. Journal of the World Aquaculture Society, New Jersey, v. 45, n. 1, p. 28-34, 2014.

FOOD AND AGRICULTURE ORGANIZATION FAO. The state of world fisheries and aquaculture 2016 contributing to food security and nutrition for all. Roma: FAO, 2016. 200 p. Available at: $<$ http://www.fao.org/3/ai5555e.pdf $>$. Accessed at: 2 feb. 2017.

FRACALOSSI, D. M.; MEYER, G.; SANTAMARIA, F. M.; WEINGARTNER, M.; ZANIBONI FILHO, E. Desempenho do jundiá, Rhamdia quelen, e dourado, Salminus brasiliensis, em viveiros de terra na região sul do Brasil. Acta Scientiarum. Animal Sciences, Maringá, v. 26, n. 3, p. 345-352, 2004.

FRECCIA, A.; SOUSA, S. M. de N.; MEURER, F.; BUTZGE, A. J.; MEWES, J. K.; BOMBARDELLI, R. A. Essential oils in the initial phase of broodstock diets of Nile tilápia. Revista Brasileira de Zootecnia, Viçosa, MG, v. 43, n. 1, p. 1-7, 2014.

GIANNENAS, I.; FLOROU-PANERI, P.; PAPAZAHARIADOU, M.; CHRISTAKI, E.; BOTSOGLOU, N. A.; SPAIS, A. B. Effect of dietary supplementation with oregano essential oil on performance of broilers after experimental infection with Eimeria tenella. Archives of Animal Nutrition, London, v. 57, n. 2, p. 99-106, 2003.

GOLDENFARB, P. B.; BOWYER, F. P.; HALL, E.; BROSIOUS, E. Reproducibility in the hematology laboratory: the microhematócrito determination. American Journal of Clinical Pathology, Hagerstown, v. 56, n. 1, p. 35-39, 1971.

GOMES, L. de C.; GOLOMBIESKI, J. I.; GOMES, A. R. C.; BALDISSEROTTO, B. Biologia do jundiá Rhamdia quelen (Teleostei, Pimelodidae). Ciência Rural, Santa Maria, v. 30, n. 1, p. 179-185, 2000.

GOULART, F. R.; SPERONI, C. S.; LOVATTO, N. M.; LOUREIRO, B. B.; CORRÊIA, V.; RADÜNZ NETO, J.; PICOLLI, L. Atividade de enzimas digestivas e parâmetros de crescimento de juvenis de jundiá (Rhamdia quelen) alimentados com farelo de linhaça in natura e demucilada. Semina: Ciências Agrárias, Londrina, v. 34, n. 6, p. 3069-3080, 2013.

HARIKRISHNAN, R.; BALASUNDARAM, C.; HEO, M. Impact of plant products on innate and adaptive immune system of cultured finfish and shellfish. Aquaculture, Amsterdam, v. 317, n. 1-4, p. 1-15, 2011.

HIGH LEVEL PANEL OF EXPERTS - HLPE. High level panel of experts on food security and nutrition of the committee on world food security. Sustainable fisheries and aquaculture for food security and nutrition. Roma: FAO, 2014. Available at: <http://www.fao.org/3/ a-i3844e.pdf $>$. Accessed at: 12 apr. 2015.

JENEY, G.; YIN, G.; ARDÓ, L.; JENEY, Z. The use of immunostimulating herbs in fish. An overview of research. Fish Physiology and Biochemistry, Amsterdam, v. 35, n. 4, p. 669-676, 2009.

KANASHIRO, M. Y. Avaliação do óleo de orégano em dietas para lambaris-do-rabo-amarelo (Astyanax altiparanae) em diferentes densidades de estocagem. 2015. Dissertação (Mestrado em Biologia Animal) Universidade Federal de Viçosa, Viçosa, MG.

KARAGOUNI, E.; ATHANASSOPOULOU, F.; LYTRA, A.; KOMIS, C.; DOTSIKA, E. Antiparasitic and immunomodulatory effect of innovative treatments against Myxobolus sp. infection in Diplodus puntazzo. Veterinary Parasitology, Amsterdam, v. 134, n. 3-4, p. 215-228, 2005.

LAZZARI, R.; RADÜNZ NETO, J.; EMANUELLI, T.; PEDRON, F. A.; COSTA, M. L.; LOSEKANN, M. E.; CORRÊIA, V.; BOCH, V. C. Diferentes fontes proteicas para a alimentação do jundiá (Rhamdia quelen). Ciência Rural, Santa Maria, v. 36, n. 1, p. 240-246, 2006. 
LOSEKANN, M.E.; RADÜNZNETO, J.;EMANUELLI, T.; PEDRON, F. de A.; LAZZARI, R.; BERGAMIN, G. T.; CORREIA, V.; SIMÕES, R. S. Alimentação do jundiá com dietas contendo óleos de arroz, canola ou soja. Ciência Rural, Santa Maria, v. 38, n. 1, p. 225-230, 2008.

LOVATTO, N. M.; PICOLLI, L. S.; LOUREIRO, B. B.; GOULART, F. R.; PRETTO, A.; SPERONI, C. S.; RADÜNZ NETO, J.; LORO, V. L. Efeitos de dietas contendo concentrados proteicos vegetais no desempenho e atividade de enzimas digestivas de jundiá (Rhamdia quelen). Semina: Ciências Agrárias, Londrina, v. 35, n. 2, p. 1071-1082, 2014.

MICHIELS, J.; MISSOTTEN, J.; HOORICK, A. V.; OVYN, A.; FREMAUT, D.; DE SMET, S.; DIERICK, N. Effects of dose and formulation of carvacrol and thymol on bacteria and some functional traits of the gut in piglets after weaning. Archives of Animal Nutrition, London, v. 64, n. 2, p. 136-154, 2010.

MUELBERT, B.; BORBA, R. M. de; WEINGARTNER, M.; SADO, R.; NUNES, J. S.; REMOR, E. As normas brasileiras de certificação orgânica para a piscicultura. In: PEREIRA, G. R.; PIRES, H. da S.; FERREIRA, L. S. B. P.; KANGERSKI, K. W. Piscicultura continental com enfoque agroecológico. Gaspar: Publicação do IFSC, 2016. p. 129-148.

NATT, M. P.; HERRICK, C. A. Anew blood diluent for counting the erythrocytes and leucocytes of the chicken. Poultry Science, Savoy, v. 31, n. 4, p. 735-738, 1952.

PÁDUA, S. B.; MENEZES FILHO, R. N. de; DIAS NETO, J.; JERÔNIMO, G. T.; ISHIKAWA, M. M; MARTINS, M. L. Ictiofitiríase: conhecendo a doença para elaborar estratégias de controle. Panorama da Aquicultura, Rio de Janeiro, v. 22, n. 131, p. 22-31, 2012.

RADÜNZ NETO, J.; BORBA, M. R. de. Exigências nutricionais e alimentação do jundiá. In: FRACALOSSI, D. M.; CYRINO, J. E. P. (Ed.). Nutriaqua: nutrição e alimentação de espécies de interesse para a aquicultura brasileira. Florianópolis: Sociedade Brasileira de Aquicultura e Biologia Aquática, 2012. p. 241-254.

ROCHA, C. B.; POUEY, J. L. O. F.; ENKE, D. B. S.; XAVIER, E. G.; ALMEIDA, D. B. Suplementação de fitase microbiana na dieta de alevinos de jundiá: efeito sobre o desempenho produtivo e as características de carcaça. Ciência Rural, Santa Maria, v. 37, n. 6, p. 17721778, 2007.

ROSENFELD, G. Corante pancrômico para hematologia e citologia clínica. Nova combinação dos componentes do may-grunwald e do giemsa num só corante de emprego rápido. Memorias do Instituto Butantan, São Paulo, v. 20, n. 1, p. 329-334, 1947.
SADO, R. Y.; BICUDO, A. J. A.; CYRINO, J. E. P. Hematology of juvenile pacu, Piaractus mesopotamicus (Holmberg, 1887) fed graded levels of mannan oligosaccharides (MOS). Latin American Journal of Aquatic Research, Valparaiso, v. 42, n. 1, p. 30-39, 2014.

SOUZA, M. A. A piscicultura em tanques-rede como vetor do desenvolvimento local sustentável? O caso do açude Castanhão - CE. 2010. Dissertação (Mestrado em Desenvolvimento Sustentável) - Universidade de Brasília, Brasília.

TAVARES-DIAS, M.; BARCELLOS, J. F. M.; MARCON, J. L.; MENEZES, G. C.; ONO, E. A.; AFFONSO, E. G. Hematological and biochemical parameters for the pirarucu Arapaima gigas Schinz, 1822 (Osteoglossiformes, Arapaimatidae) in net cage culture. Electronic Journal of Ichthyology, Tel Aviv, v. 3, n. 2, p. 61-68, 2007.

TAVARES-DIAS, M.; ISHIKAWA, M. M.; MARTINS, M. L.; SATAKE, F.; HISANO, H.; PÁDUA, S. B. de; JERÔNIMO, G. T.; SÁ, A. R. S. de. Hematologia: ferramenta para o monitoramento do estado de saúde de peixes em cultivo. In: SARAN-NET, A.; MARIANO, W. dos S.; SORIA, S. F. P. (Org.). Tópicos especiais em saúde e criação animal. São Carlos: Pedro \& João Editores, 2009. p. 43-80.

TAVARES-DIAS, M.; MELO, J. F. B.; MORAES, G.; MORAES, F. R. de. Características hematológicas de teleósteos brasileiros. IV. Variáveis do jundiá Rhamdia quelen (Pimelodidae). Ciência Rural, Santa Maria, v. 32, n. 4, p. 693-698, 2002.

VOLPATTI, D.; BULFON, C.; TULLI, F.; GALEOTTI, M. Growth parameters, innate immune response and resistance to Listonella (Vibrio) anguillarum of Dicentrarchus labrax fed carvacrol supplemented diets. Aquaculture Research, Oxford, v. 45, n. 1, p. 31-44, 2014.

WAHLI, T.; FRISCHKNECHT, R.; SCHMITT, M.; GABAUDAN, J.; VERLHAC, V.; MEIER, W. A comparison of the effect of silicone coated ascorbic acid and ascorbyl phosphate on the course of ichthyophthiriosis in rainbow trout, Oncorhynchus mykiss (Walbaum). Journal of Fish Diseases, Oxford, v. 18, n. 4, p. 347-355, 1995.

WINTROBE, M. M. Variations in the size and hemoglobin content of erythrocytes in the blood of various vertebrates. Folia Haematologica, Leipzig, v. 51, n. 1, p. 32-49, 1934.

XU, D.- H.; KLESIUS, P. H.; SHELBY, R. A. Immune responses and host protection of channel catfish, Ictalurus punctatus (Rafinesque), against Ichthyophthirius multifiliis after immunization with live theronts and 
sonicated trophonts. Journal of Fish Diseases, Oxford, v. 27, n. 3, p. 135-141, 2004.

YASUMARU, F. A. Influência do ácido caprílico na ração de juvenis de jundiá Rhamdia quelen no controle de Ichthyophthirius multifiliis. 2007. Dissertação (Mestrado em Aquicultura) - Universidade Federal de Santa Catarina, Florianópolis.

YILMAZ, E.; ERGÜN, S.; YILMAZ, S. Influence of carvacrol on the growth performance, hematological, non-specific immune and serum biochemistry parameters in rainbow trout (Oncorhynchus mykiss). Food and
Nutrition Sciences, Delaware, v. 6, n. 5, p. 523-531, 2015.

ZAR, J. H. Biostatistical analysis. $3^{\text {th }}$ ed. New Jersey: Prentice Hall, 1996. 662 p.

ZHENG, Z. L.; TAN, J. Y. W.; LIU, H. Y.; ZHOU, X. H.; XIANG, X.; WANG, K. Y. Evaluation of oregano essential oil (Origanum heracleoticum L.) on growth, antioxidant effect and resistance against Aeromonas hydrophila in channel catfish (Ictalurus punctatus). Aquaculture, Amsterdam, v. 292, n. 3-4, p. 214-218, 2009. 
